\title{
"In-Situ Sampling and Characterization of Naturally Occurring Marine Methane Hydrate Using the D/V JOIDES Resolution."
}

\section{TECHNICAL PROGRESS REPORT \#14 \\ Type of Report: Quarterly}

Reporting Period Start Date: January 1, 2005

Reporting Period End Date: March 31, 2005

Principal Authors: Drs. Frank R. Rack, Tim Francis, Peter Schultheiss, Philip E. Long, and Barry M. Freifeld

Date Report Issued: April 2005

\section{COOPERATIVE AGREEMENT DE-FC26-01NT41329}

Frank R. Rack (Joint Oceanographic Institutions; 1201 New York Ave., NW; Suite 400; Washington, DC, 20005; Tel: (202) 232-3900, ext. 1608;

Email: frack@joiscience.org);

Tim Francis and Peter Schultheiss (Dr Tim Francis, Geotek Ltd., 3 Faraday Close, Drayton Fields, Daventry, Northants, NN11 8RD UK);

Philip E. Long (Pacific Northwest National Laboratory; PO Box 999, Mail Stop K9-33; Richland, WA 99352); and,

Barry M. Freifeld (Lawrence Berkeley National Laboratory, Earth Sciences [ESHR], 1 Cyclotron Road Mail Stop 90R1116, Berkeley, CA 94720 


\section{DISCLAIMER}

This report was prepared as an account of work sponsored by an agency of the United States Government. Neither the United States Government nor any agency thereof, nor any of their employees, makes any warranty, express or implied, or assumes any legal liability or responsibility for the accuracy, completeness, or usefulness or any information, apparatus, product, or process disclosed, or represents that its use would not infringe privately owned rights. Reference herein to any specific commercial product, process, or service by trade name, trademark, manufacturer, or otherwise does not necessarily constitute or imply its endorcement, recommendation, or favoring by the United States Government or any agency therof. The views and opinions of authors expressed herein do not necessarily reflect those of the United States Government or any agency thereof.

The international Ocean Drilling Program is managed by Joint Oceanographic Institutions, Inc., under contract with the U.S. National Science Foundation. Funding for the program is provided by the following agencies:

Australia/Canada/Chinese Taipei/Korea Consortium for Ocean Drilling Deutsche Forschungsgemeinschaft (Federal Republic of Germany) Institut National des Sciences de l'Univers-Centre National de la Recherche Scientifique (INSU-CNRS; France)

Ocean Research Institute of the University of Tokyo (Japan)

National Science Foundation (United States)

Natural Environment Research Council (United Kingdom)

European Science Foundation Consortium for Ocean Drilling (Belgium, Denmark, Finland, Iceland, Ireland, Italy, The Netherlands, Norway, Portugal, Spain, Sweden, and Switzerland)

Marine High-Technology Bureau of the State Science and Technology Commissions of the People's Republic of China

Any opinions, findings, and conclusions or recommendations expressed in this report are those of the author(s) and do not necessarily reflect the views of the National Science Foundation, the participating agencies, Joint Oceanographic Institutions, Inc., Texas A\&M University, or Texas A\&M Research Foundation. 


\begin{abstract}
The primary activities accomplished during this quarter were continued efforts to develop plans for Phase 2 of this cooperative agreement based on the evolving operational planning for IODP Expedition 311, which will use the JOIDES Resolution to study marine methane hydrates along the Cascadia margin, offshore Vancouver Island.

IODP Expedition 311 has been designed to further constrain the models for the formation of marine gas hydrate in subduction zone accretionary prisms. The objectives include characterizing the deep origin of the methane, its upward transport, its incorporation in gas hydrate, and its subsequent loss to the seafloor. The main attention of this expedition is on the widespread seafloor-parallel layer of dispersed gas hydrate located just above the base of the predicted stability field. In a gas hydrate formation model, methane is carried upward through regional sediment or small-scale fracture permeability, driven by the tectonic consolidation of the accretionary prism. The upward moving methane is incorporated into the gas hydrate clathrate as it enters the methane hydrate stability zone. Also important is the focusing of a portion of the upward methane flux into localized plumes or channels to form concentrations of near-seafloor gas hydrate. The amount of gas hydrate in local concentrations near the seafloor is especially important for understanding the response of marine gas hydrate to climate change. The expedition includes coring and downhole measurements at five sites across the Northern Cascadia accretionary prism. The sites will track the history of methane in an accretionary prism from (1) its production by mainly microbiological processes over a thick sediment vertical extent, (2) its upward transport through regional or locally focused fluid flow, (3) its incorporation in the regional hydrate layer above the BSR or in local concentrations at or near the seafloor, (4) methane loss from the hydrate by upward diffusion, and (5) methane oxidation and incorporation in seafloor carbonate, or expulsion to the ocean.
\end{abstract}

This expedition builds on the previous Cascadia gas hydrate drilling of ODP Leg 146 and on more recent ODP Leg 204 off Oregon. Important experiments being considered for DOE/NETL funding as part of the JOI cooperative agreement include, (1) LoggingWhile-Drilling/Measurements-While-Drilling (LWD/MWD), (2) Pressure Core Sampling (PCS/HYACINTH) of gas hydrate, and fluid recovery under in situ conditions, (3) X-ray CT logging of whole cores under in situ conditions, and (4) Infrared thermal imaging of whole round cores to map temperature variations resulting from the presence of hydrate.

Preliminary budget estimates have been made for each of these tasks and discussions are ongoing with DOE/NETL program managers to develop a final plan that can be implemented within the constraints of the available funding and logistical considerations.

In-Situ Sampling and Characterization of Naturally Occurring Marine Methane Hydrate Using the D/V JOIDES Resolution. 


\section{TABLE OF CONTENTS}

Disclaimer

Abstract

Table of Contents

Introduction

Executive Summary

Experimental

Results and Discussion

Conclusion

References

List of Acronyms and Abbreviations
2

3

4

5

6

7

8

17

18

19

In-Situ Sampling and Characterization of Naturally Occurring Marine Methane Hydrate Using the D/V JOIDES Resolution. 


\section{INTRODUCTION}

The primary activities accomplished during this quarter were continued efforts to develop plans for Phase 2 of this cooperative agreement based on the evolving operational planning for IODP Expedition 311, which will use the JOIDES Resolution to study marine methane hydrates along the Cascadia margin, offshore Vancouver Island.

IODP Expedition 311 has been designed to further constrain the models for the formation of marine gas hydrate in subduction zone accretionary prisms. The objectives include characterizing the deep origin of the methane, its upward transport, its incorporation in gas hydrate, and its subsequent loss to the seafloor. The main attention of this expedition is on the widespread seafloor-parallel layer of dispersed gas hydrate located just above the base of the predicted stability field. In a gas hydrate formation model, methane is carried upward through regional sediment or small-scale fracture permeability, driven by the tectonic consolidation of the accretionary prism. The upward moving methane is incorporated into the gas hydrate clathrate as it enters the methane hydrate stability zone. Also important is the focusing of a portion of the upward methane flux into localized plumes or channels to form concentrations of near-seafloor gas hydrate. The amount of gas hydrate in local concentrations near the seafloor is especially important for understanding the response of marine gas hydrate to climate change. The expedition includes coring and downhole measurements at five sites across the Northern Cascadia accretionary prism. The sites will track the history of methane in an accretionary prism from (1) its production by mainly microbiological processes over a thick sediment vertical extent, (2) its upward transport through regional or locally focused fluid flow, (3) its incorporation in the regional hydrate layer above the BSR or in local concentrations at or near the seafloor, (4) methane loss from the hydrate by upward diffusion, and (5) methane oxidation and incorporation in seafloor carbonate, or expulsion to the ocean.

This expedition builds on the previous Cascadia gas hydrate drilling of ODP Leg 146 and on more recent ODP Leg 204 off Oregon. Important experiments being considered for DOE/NETL funding as part of the JOI cooperative agreement include, (1) LoggingWhile-Drilling/Measurements-While-Drilling (LWD/MWD), (2) Pressure Core Sampling (PCS/HYACINTH) of gas hydrate, and fluid recovery under in situ conditions, (3) X-ray CT logging of whole cores under in situ conditions, and (4) Infrared thermal imaging of whole round cores to map temperature variations resulting from the presence of hydrate.

Preliminary budget estimates have been made for each of these tasks and discussions are ongoing with DOE/NETL program managers to develop a final plan that can be implemented within the constraints of the available funding and logistical considerations. 


\section{EXECUTIVE SUMMARY}

The primary activities accomplished during this quarter were continued efforts to develop plans for Phase 2 of this cooperative agreement based on the evolving operational planning for IODP Expedition 311, which will use the JOIDES Resolution to study marine methane hydrates along the Cascadia margin, offshore Vancouver Island.

IODP Expedition 311 has been designed to further constrain the models for the formation of marine gas hydrate in subduction zone accretionary prisms. The objectives include characterizing the deep origin of the methane, its upward transport, its incorporation in gas hydrate, and its subsequent loss to the seafloor. The main attention of this expedition is on the widespread seafloor-parallel layer of dispersed gas hydrate located just above the base of the predicted stability field. In a gas hydrate formation model, methane is carried upward through regional sediment or small-scale fracture permeability, driven by the tectonic consolidation of the accretionary prism. The upward moving methane is incorporated into the gas hydrate clathrate as it enters the methane hydrate stability zone. Also important is the focusing of a portion of the upward methane flux into localized plumes or channels to form concentrations of near-seafloor gas hydrate. The amount of gas hydrate in local concentrations near the seafloor is especially important for understanding the response of marine gas hydrate to climate change. The expedition includes coring and downhole measurements at five sites across the Northern Cascadia accretionary prism. The sites will track the history of methane in an accretionary prism from (1) its production by mainly microbiological processes over a thick sediment vertical extent, (2) its upward transport through regional or locally focused fluid flow, (3) its incorporation in the regional hydrate layer above the BSR or in local concentrations at or near the seafloor, (4) methane loss from the hydrate by upward diffusion, and (5) methane oxidation and incorporation in seafloor carbonate, or expulsion to the ocean.

This expedition builds on the previous Cascadia gas hydrate drilling of ODP Leg 146 and on more recent ODP Leg 204 off Oregon. Important experiments being considered for DOE/NETL funding as part of the JOI cooperative agreement include, (1) LoggingWhile-Drilling/Measurements-While-Drilling (LWD/MWD), (2) Pressure Core Sampling (PCS/HYACINTH) of gas hydrate, and fluid recovery under in situ conditions, (3) X-ray CT logging of whole cores under in situ conditions, and (4) Infrared thermal imaging of whole round cores to map temperature variations resulting from the presence of hydrate.

Preliminary budget estimates have been made for each of these tasks and discussions are ongoing with DOE/NETL program managers to develop a final plan that can be implemented within the constraints of the available funding and logistical considerations. 


\section{EXPERIMENTAL}

Expedition 311 is based on a "light" or "slim" version of Integrated Ocean Drilling Program (IODP) drilling proposal number 553-Full2 (www.iodp-misapporo.org/active 2.html). Following ranking by the IODP Scientific Advisory Structure, the expedition was scheduled by the IODP Operations Committee for the research vessel JOIDES Resolution, operating under contract with the U.S. Implementing Organization (USIO) of the IODP. The expedition is currently scheduled to begin in Balboa, Panama on August 24, 2005, departing after a four-day port call (or when ready). The science party is scheduled to board the ship on September 10, 2005 during a one-day portcall in Astoria, Oregon, USA. The expedition officially concludes in Victoria, British Columbia, Canada on October 7, 2005 (for the current detailed schedule, see http://www.iodp.tamu.edu/scienceops). A total of 22 days will be available for the drilling, coring, and downhole measurements described in this report. Further details on the JOIDES Resolution can be found at http://www.iodp.tamu.edu.

The Scientific Prospectus for Expedition 311 is currently being drafted and should be available in the next quarter. The next section includes a summary of the current proposed activities that are being evaluated for funding during Phase 2 of this cooperative agreement and which will form the basis for some of the activities undertaken with DOE funding during IODP Expedition 311, among others. 


\title{
RESULTS AND DISCUSSION
}

\section{Proposed Pressure Coring Technology - Cascadia Margin Hydrates}

\author{
T. J. G. Francis \& P. J. Schultheiss, Geotek Ltd
}

\section{Introduction}

The study of gas hydrates, and of the deep biosphere beneath the ocean floor, are two important scientific thrusts of the Integrated Ocean Drilling Program (IODP). Progress in these two areas of research will depend on the successful application of new technologies, which were only beginning to yield a scientific return in the earlier Ocean Drilling Program. Retrieving cores under full hydrostatic pressures, 'pressure coring', together with the means of making detailed measurements on such cores retained at in situ pressures, are critical technologies needed for the study of gas hydrates and the deep biosphere. This paper briefly reviews the pressure coring tools and associated equipment that are currently available for use on the IODP leg dedicated to the Cascadia Margin Hydrates, and recommends the use of both the Pressure Core Sampler (PCS) and the HYACINTH pressure coring system.

Proposed drill sites on the Cascadia Margin

Operations have been proposed at the following sites on the Cascadia margin (Riedel, 2003):

\begin{tabular}{|c|c|c|c|c|c|c|}
\hline \multirow[t]{2}{*}{ Site Name } & \multirow[t]{2}{*}{ Position } & \multirow{2}{*}{$\begin{array}{l}\text { Water } \\
\text { depth } \\
\text { (m) }\end{array}$} & \multicolumn{3}{|c|}{ Penetration (m) } & \multirow{2}{*}{$\begin{array}{c}\text { Brief Site-specific } \\
\text { objectives }\end{array}$} \\
\hline & & & Sed & Bsm & Total & \\
\hline CAS-04B & $\begin{array}{l}48^{\circ} 34^{\prime} \mathrm{N} \\
127^{\circ} 10^{\prime} \mathrm{W}\end{array}$ & 2600 & 500 & 0 & 500 & $\begin{array}{l}\text { Site will provide important } \\
\text { reference information about } \\
\text { the sediments that do not } \\
\text { contain gas and/or gas hydrate }\end{array}$ \\
\hline CAS-03B & $\begin{array}{l}48^{\circ} 37.15^{\prime} \mathrm{N} \\
127^{\circ} \\
03.45^{\prime} \mathrm{W}\end{array}$ & 2000 & 400 & 0 & 400 & $\begin{array}{l}\text { Characterize fluid expulsion } \\
\text { and related hydrate formation }\end{array}$ \\
\hline CAS-02B & $\begin{array}{l}48^{\circ} 38.57^{\prime} \mathrm{N} \\
127^{\circ} 00.0^{\prime} \mathrm{W}\end{array}$ & 2150 & 400 & 0 & 400 & $\begin{array}{l}\text { Characterize fluid expulsion } \\
\text { and related hydrate formation }\end{array}$ \\
\hline CAS-01B & $\begin{array}{l}48^{\circ} 41.98^{\prime} \mathrm{N} \\
126^{\circ} 52.1^{\prime} \mathrm{W}\end{array}$ & 1400 & $\begin{array}{l}600 \\
400 \\
400\end{array}$ & 0 & 600 & Dual ACORK experiment \\
\hline CAS-05B & $\begin{array}{l}48^{\circ} 46.0^{\prime} \mathrm{N} \\
126^{\circ} \\
43.45^{\prime} \mathrm{W}\end{array}$ & 1100 & 350 & 0 & 350 & $\begin{array}{l}\text { Last Site along transect, } \\
\text { shallowest BSR occurrence }\end{array}$ \\
\hline CAS-06A & $\begin{array}{l}48^{\circ} 40.0^{\prime} \mathrm{N} \\
126^{\circ} 51.0^{\prime} \mathrm{W}\end{array}$ & 1400 & 350 & 0 & 350 & $\begin{array}{l}\text { Vent field, focused fluid flow } \\
\text { and near-seafloor hydrate } \\
\text { formation }\end{array}$ \\
\hline CAS-07A & $\begin{array}{l}49^{\circ} 11.0^{\prime} \mathrm{N} \\
127^{\circ} 52.0^{\prime} \mathrm{W}\end{array}$ & 2600 & 600 & 0 & 600 & $\begin{array}{l}\text { Nootka fault, earthquake } \\
\text { induced fluid expulsion }\end{array}$ \\
\hline
\end{tabular}


All the sites are within the depth capability of the PCS. Apart from sites CAS-04B and CAS-07A, both in $2600 \mathrm{~m}$ water depth, the sites are all within the depth capability of the HYACINTH pressure corers and laboratory chambers. The primary sites for sampling hydrates are CAS-02B, CAS-03B, CAS-05B and CAS-06A.

\section{Existing wireline pressure corers}

Four wireline-retrievable pressure corers that have been used to recover pressure cores from the seabed are currently in existence, PCS, PTCS, FPC and HRC;

1) Pressure Core Sampler (PCS). This tool was developed by ODP, building on earlier DSDP developments, and is compatible with the Bottom Hole Assembly used for the APC and XCB coring systems in ODP and now in use with IODP (Pettigrew, 1992). The tool was successfully used for scientific purposes on ODP Legs 164, 201 and 204. Test deployments were carried out on other ODP legs. A major redesign of the PCS took place between Legs 164 and 201 (Schroeder, 2003). As currently configured, the PCS can acquire a core sample $43.2 \mathrm{~mm}$ in diameter and up to $1 \mathrm{~m}$ in length, at pressures up to 689.7 bar (10,000 psi) which are retained using a ball valve. Thus the tool can acquire pressure cores in full oceanic depths up to a maximum combined water depth and bottom penetration of $\sim 6,500 \mathrm{~m}$. The PCS latches into the BHA, is rotated by rotating the whole drill string, and can core formations composed of soft sediments to firm clay..

2) Pressure Temperature Core Sampler (PTCS). This tool was designed and built by Aumann \& Associates Inc. in 1996-97 in the United States for the Research Consortium for Methane Hydrate Resources in Japan, and is operated by the JNOC Technology Research Center. In some respects the design draws on that of the ODP PCS, for example the tool rotates with the drill string and pressure is sealed with a ball valve, but in order to preserve hydrate cores in the best possible condition the PTCS, as originally specified, aimed to retain the temperature of the core as well as the pressure. However, we understand that this development is not now used. Because the objective of the Japanese research is to assess hydrate resources, a larger core is desirable and the PTCS is designed to acquire a sample $66 \mathrm{~mm}$ in diameter and up to $3 \mathrm{~m}$ in length. It can recover a core up to a maximum pressure of 241.4 bar (3,500 psi). The tool was deployed in wells in the Nankai Trough in 1999 and, after major redesign, it was again deployed extensively off Japan in early 2004 apparently with good success rates. However, the maximum OD of the tool is 5.437" (138.1 mm), so that the PTCS is too large to pass through the ODP/IODP drill string used on the JOIDES Resolution, which has a bore of $4.125^{\prime \prime}(104.7 \mathrm{~mm})$. Thus using the PTCS from the JOIDES Resolution is not an option for the Cascadia Leg.

HYACINTH coring systems. Two wireline pressure coring tools, the FPC and HRC were designed and built as part of the European-funded HYACE project (HYdrate Autoclave Coring Equipment) and refined during the subsequent HYACINTH project (Deployment of HYACe tools In New Tests on Hydrates). Both these tools enable core to be recovered

In-Situ Sampling and Characterization of Naturally Occurring Marine Methane Hydrate Using the D/V JOIDES Resolution. 
and retained up to a maximum pressure of 250 bar (3,625 psi) using specially designed flap valves. The corers have been designed to allow the core to be transferred, without loss of pressure, into laboratory chambers for study and analysis. After testing on ODP Legs 194 and 201, the HYACINTH coring tools provided their first pressure cores for scientific analysis on ODP Leg 204. Because both the tools use 'dry' cutting mechanisms in a non rotating drill string they probably take relatively uncontaminated samples when compared with other tools that flush at the bit with drilling mud or water (Schultheiss et al. 2004).

3)F ugro Pressure Corer (FPC). The FPC was designed and built by Fugro Engineers $\mathrm{BV}$ in The Netherlands. It is a percussion corer, which uses a water hammer driven by the fluid circulation to drive the core barrel into the sediment up to $1 \mathrm{~m}$ ahead of the roller cone bit, and is suitable for sampling unlithified sediments ranging from soft or stiff clays to sandy and gravelly material. It acquires a core $57 \mathrm{~mm}$ in diameter and up to $1 \mathrm{~m}$ in length in a plastic liner whose OD is $63 \mathrm{~mm}$.

4) HYACE Rotary Corer (HRC). The HRC was designed and built by the Technical University of Clausthal and the Technical University of Berlin in Germany. It uses a downhole motor driven by the fluid circulation to cut a core up to $1 \mathrm{~m}$ ahead of the roller cone bit in lithified sediment or rock. It acquires a core $51 \mathrm{~mm}$ in diameter and up to $1 \mathrm{~m}$ in length in a plastic liner whose OD is $56 \mathrm{~mm}$.

\section{Comparison of the PCS, FPC and HRC}

All pressure-coring tools are complex devices when compared to ordinary wireline corers recovering cores to atmospheric pressure. The PCS is the most mature of the pressure corers discussed here. Building on the experience of various pressure coring developments within the Deep Sea Drilling Project (1968-83), the PCS design was completed in the late eighties. The tool was tested at sea before its first major scientific operation on Leg 164 in 1995 (Rack, 2001). Major redesign and further testing followed before the next scientific deployments on Leg 201 and 204. To date the PCS has been deployed about a hundred times. With time and experience it has become a reliable tool, which is one of its principal advantages together with its ability to operate to full ocean depths. The principal disadvantages of the PCS are the small core diameter (limited by the ball valve), the core quality and the fact that there is no method of transferring the pressurized core from the PCS sample chamber into a laboratory pressure chamber for further analysis.

The FPC and HRC tools have been developed more recently and designed to overcome many of the disadvantages of the PCS. The principal, and overriding, advantage of these coring systems are that the recovered cores can be transferred (in their liner) from the corer, without loss of pressure, into laboratory chambers where measurements (nondestructive and destructive) and sub-samples can be obtained at full in situ hydrostatic pressures. The design and method of operation of the FPC and HRC also provide higher 
quality cores that are likely to be less contaminated than cores from other sampling tools (very important for microbiological and geochemical applications). The HRC has the capability of drilling in hard rock formations. Their principal disadvantages are that their reliability is not yet as good as the PCS, and that they are limited to a maximum working pressure of 250 bar, equivalent to a combined water depth and penetration of c. 2,500 m.

\section{Analyzing pressure cores acquired from the PCS}

The pressure chamber in which the core sample is retained is removed from the PCS, carried to the laboratory for analysis and placed in an ice bath to maintain the interior temperature at about $0^{\circ} \mathrm{C}$. A manifold with a pressure transducer is connected and the core is slowly and incrementally depressurized with the gas being collected in a bubbling chamber. The volume of gas released and the pressure are recorded against time, and the gas analyzed. The data acquired allows the total amount and nature of the gas in the core to be determined (Milkov et al., 2004). Whether the gas existed in the core as hydrate or in solution can also be inferred by reference to known phase diagrams. It is not possible to remove the core from the chamber for examination and sub-sampling until it has been completely depressurized.

\section{Analyzing pressure cores acquired with the FPC or HRC}

In parallel with the development of the FPC and HRC, a whole family of connecting chambers has been developed within the scope of the HYACINTH project. This equipment enables the core to be released and removed from the corer and transferred into measurement or storage chambers while still under full pressure (up to 250 bar). Once the core has been removed from the corer a versatile manipulator system enables the core to be transferred between chambers for different applications. GRP chambers have been used for $\mathrm{P}$ wave velocity and gamma density measurements, while steel chambers are used for storage (also used for gamma density measurements). More recently high pressure aluminium alloy chambers have been built which will enable the HYACINTH cores to be scanned with the portable X-ray CT system developed at Lawrence Berkeley National Laboratory (Freifeld et al. 2003). When a pressure core has been logged at in situ pressure, it can then be slowly and incrementally depressurized in the same manner as is done with the PCS cores.

Repeated gamma density logging of HRC and FPC cores on ODP Leg 204 while they were being depressurized showed where gas was being generated and thus where hydrate existed in the original core. Conspicuous zones of low density were also observed at a few locations in the cores and interpreted to be due to the presence of hydrate (Tréhu et al., 2003; Francis \& Schultheiss, 2003). The logging of HRC and FPC cores on ODP Leg 204 was hampered by the lack of a refrigerated room in which to carry out the work. The vertical MSCL equipment was set up in the warm environment of the ship's scientific hold. Consequently, during the course of logging the hydrate-bearing cores, the pressure chambers warmed up and had to be periodically returned to one of the ship's refrigerated

In-Situ Sampling and Characterization of Naturally Occurring Marine Methane Hydrate Using the D/V JOIDES Resolution. 
core stores to cool down in order to ensure that the $\mathrm{P} / \mathrm{T}$ state of the core remained within the hydrate stability zone. A proper refrigerated space should be made available on board the JOIDES Resolution for the next dedicated hydrate leg, to enable the geophysical logging of hydrate pressure cores to be more efficiently carried out. Both the Geotek vertical MSCL equipment and the Lawrence Berkeley portable CT system should be located in this space. Ideally, it should also be used for the transfer system, used to extract the HRC and FPC pressure cores from the corers and transfer them into laboratory chambers. On ODP Leg 204, transfers were made in the open air on the upper deck of the labstack, with ice bags being used to keep the cores cool - a not altogether satisfactory arrangement.

Other equipment is also under development, which will take advantage of the fact that cores from the FPC and HRC can be manipulated under pressure. It includes instrumented chambers that will allow other measurements to be made - e.g. 3D electrical resistivity, P \& S wave velocity and shear strength. Other important systems are nearing completion that will enable sub-samples to be cut from a core and transferred into smaller chambers. The smaller sub-sample chambers can be connected to a microbiological system of chambers, where the central part of the sub-sample can be extruded in a sterile manner and cut into slivers of material for studying barophilic microorganisms by culturing them under pressure. Some of this equipment will be ready to be tested and used on HRC and FPC pressure cores acquired on the Cascadia margin. However, it will not be necessary for all of this equipment to be deployed on board the drillship. A shore-based laboratory should be set up, close to where the ship docks at the end of the leg, to enable a range of physical properties, sub-sampling and microbiological experiments to be carried out. HRC and FPC pressure cores could be brought back in Storage Chambers (SCs) from the leg to supply the shore-based laboratory, which the material required. At the present time there are $11 \mathrm{SCs}$ in the HYACINTH family, seven constructed from stainless steel and four in which the cylindrical tube is composed from aluminium alloy. In addition there are two pressure chambers in which the cylindrical tube is manufactured from GRP. With proper planning, we estimate that there are more than enough chambers to allow for substantial shore-based work to be carried out on cores in their pristine state.

\section{Conclusions}

An important discovery of ODP Leg 204 was the heterogeneous distribution of gas hydrates within the gas hydrate stability zone (Tréhu et al., 2004). This result was achieved by integrating the data obtained from several different techniques. Both the PCS and the HYACINTH system contributed to this finding: thirty successful PCS pressure cores were acquired and degassed, while six HRC and FPC pressure cores were repeatedly logged while degassing. The geophysical logging of pressure cores allowed the distribution of hydrate within them to be studied at a centimeter scale, a much higher resolution than is possible with PCS cores. We conclude that in order to understand the distribution of hydrates in the Cascadia margin, it is necessary to deploy as wide a range

In-Situ Sampling and Characterization of Naturally Occurring Marine Methane Hydrate Using the D/V JOIDES Resolution. 
of sampling and measurement techniques as possible, including both the PCS and the HYACINTH system. The HYACINTH cores should be logged with the MSCL system as used on ODP Leg 204 and with the Lawrence Berkeley portable X-ray CT system, in order to define the fine scale distribution of gas hydrate within them. In addition, by deploying the HYACINTH system on the Cascadia leg, it will be possible to transfer pristine pressure cores to shore for more detailed study.

\title{
Preliminary Proposal for IR imaging for Cascadia Margin
}

\author{
Philip E. Long, Pacific Northwest National Laboratory
}

Introduction

IR imaging of gas hydrate cores was successfully conducted during Leg 204 of the Ocean Drilling Program, creating a new and independent proxy for gas hydrate abundance, texture, and distribution as well as providing rapid identification of hydrate-bearing zones for immediate sampling and preservation (See Trehu, Long, et al. 2004). IR imaging of cores enables detection of gas hydrate through the core liner because of the endothermic nature of the dissociation reaction. When gas hydrate dissociates to methane plus water, the hydrate, and any surrounding sediment is cooled providing a thermal signature that can be imaged. Application of IR imaging to gas hydrate cores now ranges from informal, handheld image capture of parts of cores, to rolling a camera along a core on deck while collecting images at 60 frames/second, to the systematic capture of images every $20 \mathrm{~cm}$ along all cores that was done on Leg 204. While IR imaging on Leg 204 produced exceptional information on gas hydrate, data collection rate and data processing limited full exploitation of the data. The data collection did not take full advantage of the data rate of the IR cameras and data analysis was a slow process involving a number of manual steps, all of which can now be automated.

\section{Opportunity Provided by the Cascadia Margin Hydrates IODP Expedition}

In December 2004, the Integrated Ocean Drilling Program (IODP) decided to go forward with a proposed expedition to drill and sample gas hydrates on the Cascadia Margin off Vancouver Island. Nominally scheduled for late August-September, 2005, this expedition will provide the opportunity to examine gas hydrate occurrence and abundance in a convergent margin without the focused flow that characterizes Hydrate Ridge, offshore Oregon. Data from this expedition will thus be critical to assessing general convergent margin hydrate abundances. Results will be critical to resource assessment, impact of gas hydrate on climate, and on the safety of off-shore drilling rigs. To take full advantage of this opportunity, we need to optimize our ability to assess gas hydrate abundance using IR imaging, the objective of this proposal. While this proposal is focused on the upcoming IODP expedition, the equipment we propose will be readily portable for use on other sea-going and land-based drilling for gas hydrates, such as the 
Gulf of Mexico hydrate JIP (beyond Leg 1) and future sub-permafrost drilling. It is also important to note that planning for the IODP Expedition 311 is in progress and the IR imaging proposed here must, and will be fully coordinated with IODP-USIO (JOI Alliance). To initiate this coordination, we have discussed this project with Frank Rack (Director, USIO/JOI Alliance) and expect to participate in or contribute information to planning meetings for the expedition.

Summary of Proposed Enhancement for IR Imaging on the IODP Expedition 311 Based on ODP Leg 204 experience, a relatively small additional investment in IR imaging can create significant advances in the detection and quantification (nature and distribution) of gas hydrates in cores. For IODP Expedition 311 we propose to use 3 existing DOE-owned IR cameras on fixed mounts to image the full circumference of the core liner (or a horizontally split core) at about the same speed the core is moved from the rig floor to the core processing area. Images collected will be automatically stitched and concatenated enabling complete circumferential image "wrapping" to allow display of virtual core cylinders. This will significantly aid the structural interpretation of hydrates and enable a detailed comparison to be made with down-hole RAB or FMI images, if these are available. In addition, the new system will enable the horizontally split surface of cores to be imaged. IR scanning performed on split cores immediately after recovery will reveal far more detailed information on gas hydrate structure than previously possible. This capability will also permit multiple scans to track the thermal history through time enhancing the accuracy of the gas hydrate abundance estimates. Finally, new techniques, using image analysis tools, will be employed to automatically extract data on gas hydrate abundance, texture, and distribution as a function of depth.

Proposed work tasks

Design and construct a versatile automated IR imaging frame for cores. This will use fixed camera mounts with a passive core transport mechanism capable of tracking core depth and imaging $360^{\circ}$ of the core circumference at mm-scale spatial resolution. Either whole cores (of any length) or split/whole core sections (1.5 m long) will be capable of being imaged.

Develop data export, image rectification, and concatenation routines that will produce continuous IR images of the complete core liner surface in near real time. Images will be displayed rapidly enough to permit review while core is being sampled for gas hydrate. Adapt off-the-shelf image analysis software to permit rapid shipboard and later shorebased analysis of gas hydrate abundance, texture, and distribution as a function of depth. 


\section{X-ray CT and Hydrate Pressure Coring for IODP Expedition 311}

\section{Barry Freifeld (Lawrence Berkeley National Laboratory)}

The Berkeley Laboratory portable x-ray CT was originally developed for imaging cores during ODP Leg 204, Drilling Gas Hydrates on Cascadia Continental Margin. The X-ray CT was also deployed on the Hot Ice \#1 borehole, located in the North Slope of Alaska, near Kuparuk Field, as well as on ODP Leg 210. Although work at Hot Ice \#1 did not recover hydrates, the characterization of ice-lens morphology in addition to detailed sedimentary structure highlight the portable x-ray CT system's ability to discern submillimeter details.

By deploying the $\mathrm{x}$-ray $\mathrm{CT}$ along with pressure coring equipment during IODP Expedition 311, decisions can be made on how to best use pressure cores, while they are still within the hydrate stability region. Based on what the CT reconstructions reveal, a detailed sequence of lab tests can be determined - and most importantly, the core can be imaged prior to undergoing decomposition to determine hydrate-sediment structure.

For the ChevronTexaco Joint Industry Partnership (GOM JIP) drilling expedition in the Gulf of Mexico, scheduled to start April 4, the X-ray CT has been completely redesigned from the original ODP Leg 204 configuration, to facilitate scanning in aluminum pressure core storage vessels. Currently four of these vessels have been built for the GOM JIP, with pressure ratings of 250 bars for three of the units and 150 bars for the fourth unit. Because the $\mathrm{x}$-ray $\mathrm{CT}$ will be operating in a $4^{\circ} \mathrm{C}$ cold room, the pressure cores will be well within the hydrate stability region while working in the CT scanner.

Performing degassing experiments on hydrate-bearing core, while the core is being CT scanned, allows for detailed characterization of the hydrate spatial distribution within the core. By acquiring a set of baseline images and differencing the images as the core is brought out of the hydrate stability region, detailed information on the kinetics of hydrate dissociation and the interaction of hydrate with the host sediment is obtained. In the new $\mathrm{X}$-ray CT design, the x-ray source and imager rotate around the core, allowing the connection of high-pressure gas lines, thermocouples, and fluid jackets for temperature control. The X-ray CT systems image resolution has also been increased from 200 microns to 100 microns. The instrument is cabinet safe, allowing operating personnel to stand next to the instrument while it is operating.

Having precise registration of the core is needed when performing image differencing. With the pressure core vessel carriage mounted on precision hardened shafts, driven by an ACME thread lead screw, translational accuracy is better than $250 \mathrm{~m}$ across the entire core, with a repeatability of $50 \mathrm{~m}$.

It is proposed for IODP Expedition 311 that the X-ray CT be incorporated into a cold container, similar to the installation for the GOM JIP. A cold container has been 
suggested as the best location to perform the transfer of the pressure core from the core barrel to the storage chamber. If a cold container is available and the aluminum pressure vessels are available, all of the laboratory equipment now being deployed for core characterization studies for the GOM JIP can also be used for IODP Expedition 311 without further modification. This equipment includes several specialized core holders instrumented with multiple thermocouples, as well as four, 42 liter Mariotte style flowmeters, used for degassing studies. The volume of gas evolved and temperature measurements are logged automatically using a computer data acquisition system. In addition, a portable quadrupole mass spectrometer is incorporated into the flowmeter system to give real-time analysis of evolved gases. 


\section{CONCLUSION}

The primary activities accomplished during this quarter were continued efforts to develop plans for Phase 2 of this cooperative agreement based on the evolving operational planning for IODP Expedition 311, which will use the JOIDES Resolution to study marine methane hydrates along the Cascadia margin, offshore Vancouver Island.

IODP Expedition 311 has been designed to further constrain the models for the formation of marine gas hydrate in subduction zone accretionary prisms. The objectives include characterizing the deep origin of the methane, its upward transport, its incorporation in gas hydrate, and its subsequent loss to the seafloor. The main attention of this expedition is on the widespread seafloor-parallel layer of dispersed gas hydrate located just above the base of the predicted stability field. In a gas hydrate formation model, methane is carried upward through regional sediment or small-scale fracture permeability, driven by the tectonic consolidation of the accretionary prism. The upward moving methane is incorporated into the gas hydrate clathrate as it enters the methane hydrate stability zone. Also important is the focusing of a portion of the upward methane flux into localized plumes or channels to form concentrations of near-seafloor gas hydrate. The amount of gas hydrate in local concentrations near the seafloor is especially important for understanding the response of marine gas hydrate to climate change. The expedition includes coring and downhole measurements at five sites across the Northern Cascadia accretionary prism. The sites will track the history of methane in an accretionary prism from (1) its production by mainly microbiological processes over a thick sediment vertical extent, (2) its upward transport through regional or locally focused fluid flow, (3) its incorporation in the regional hydrate layer above the BSR or in local concentrations at or near the seafloor, (4) methane loss from the hydrate by upward diffusion, and (5) methane oxidation and incorporation in seafloor carbonate, or expulsion to the ocean.

This expedition builds on the previous Cascadia gas hydrate drilling of ODP Leg 146 and on more recent ODP Leg 204 off Oregon. Important experiments being considered for DOE/NETL funding as part of the JOI cooperative agreement include, (1) LoggingWhile-Drilling/Measurements-While-Drilling (LWD/MWD), (2) Pressure Core Sampling (PCS/HYACINTH) of gas hydrate, and fluid recovery under in situ conditions, (3) X-ray CT logging of whole cores under in situ conditions, and (4) Infrared thermal imaging of whole round cores to map temperature variations resulting from the presence of hydrate.

Preliminary budget estimates have been made for each of these tasks and discussions are ongoing with DOE/NETL program managers to develop a final plan that can be implemented within the constraints of the available funding and logistical considerations. 


\section{REFERENCES}

Francis, Tim \& Peter Schultheiss, 2003. Leg 204: geophysical logging of gas hydrate cores at in situ pressure, UKODP Newsletter, 29, 11-14, 2003.

Freifeld, B.M., T.J. Kneafsey, J. Pruess and L. Tomutsa, 2003. Field characterization of hydrate-bearing core using X-ray computed tomography, presented at the GSA Hydrate Special Session, November 5, 2003.

Milkov, A.V., G.R. Dickens, G.E. Claypool, Y-J. Lee, W.S. Borowski, M.E. Torres, W. $\mathrm{Xu}, \mathrm{H}$. Tomaru, A.M. Tréhu and P. Schultheiss, 2004. Co-existence of gas hydrate, free gas, and brine within the regional gas hydrate stability zone at Hydrate Ridge (Oregon margin): evidence from prolonged degassing of a pressurized core, Earth Planet. Sci. Lett. 222: 829-843.

Pettigrew, T., 1992. Design and operation of a wireline pressure core sampler (PCS), ODP Technical Note, 17 (Ocean Drilling Program): College Station, TX.

Riedel, M, R.D.Hyndman, E.E. Davis, T.S. Collett, D. Bartlett, M.A. Kastner, G.D. Spence and S.R. Dallimore, 2003. Gas Hydrates on the Canadian Margin, IODP proposal 553-Full2.

Schultheiss, P. J., T.J.G. Francis, M. Holland, J.A. Roberts, H. Amann, Thjunjoto, R.J. Parkes, D. Martin, M. Rothfuss, F. Tyunder \& P.D. Jackson, 2004. Pressure Coring, Logging and Sub-Sampling with the HYACINTH system, in "New ways of looking at sediment cores and core data", Geol. Soc. Spec. Pub. (in press).

Rack, F.R., 2001. Preliminary Evaluation of Existing Pressure/Temperature Coring System: Washington, D.C. (Joint Oceanographic Institutions). Available from World Wide Web: <http://NETL.CERTREC.COM> Login = NETL; Password = ARCHIVE; File Name = HYD_00037_2001.PDF [Cited 2004-02-15].

Schroeder, D., 2003. Pressure Core Sampler - PCS, presented at the International Pressure Coring Meeting held at ODP, College Station, TX, February 5-7, 2003.

Tréhu, A.M, Bohrmann, G., Rack, F.R., Torres, M.E., et al., 2003. Proc. ODP, Init. Repts., 204 [CD-ROM]. Available from: Ocean Drilling Program, Texas A\&M University, College Station TX 77845-9547, USA.

Tréhu, A.M., P.E. Long, M.E. Torres, G. Bormann, F.R. Rack and Leg 204 Shipboard Scientific Party, 2004. Three-dimensional distribution of gas hydrate beneath southern Hydrate Ridge: constraints from ODP Leg 204, Earth Planet. Sci. Lett. 222:845-862. 


\section{LIST OF ACRONYMS AND ABBREVIATIONS}

$\begin{array}{ll}\text { APC } & \text { Advanced Piston Corer } \\ \text { APC-M } & \text { Advanced Piston Corer-methane tool } \\ \text { APC-T } & \text { Advanced Piston Corer-temperature tool } \\ \text { BHA } & \text { Bottom Hole Assembly } \\ \text { BSR } & \text { Bottom Simulating Reflector } \\ \text { DOE } & \text { Department of Energy } \\ \text { DVTP } & \text { Davis Villinger Temperature Probe } \\ \text { DVTP-P } & \text { Davis Villinger Temperature Probe with Pressure } \\ \text { FMMG } & \text { Fugro-McCleland Marine Geosciences } \\ \text { FPC } & \text { Fugro Pressure Corer } \\ \text { GHSZ } & \text { Gas Hydrate Stability Zone } \\ \text { HR } & \text { Hydrate Ridge } \\ \text { HRC } & \text { HYACE Rotary Corer } \\ \text { HYACE } & \text { Hydrate Autoclave Coring Equipment } \\ \text { HYACINTH } & \text { Deployment of HYACE tools In New Tests on Hydrates } \\ \text { IR-TIS } & \text { Infrared Thermal Imaging System } \\ \text { JOI } & \text { Joint Oceanographic Institutions } \\ \text { JOIDES } & \text { Joint Oceanographic Institutions for Deep Earth Sampling } \\ \text { LDEO } & \text { Lamont Doherty Earth Observatory (Columbia University) } \\ \text { L/L } & \text { Liters per Liter } \\ \text { LTC } & \text { Laboratory Transfer Chamber } \\ \text { LWD } & \text { Logging While Drilling } \\ \text { MBRF } & \text { Meters Below Rig Floor } \\ \text { MBSF } & \text { Meters Below Sea Floor } \\ \text { MH } & \text { Methane Hydrate } \\ \text { MPa } & \text { Mega-Pascals } \\ \text { MSCL-V } & \text { Multi-Sensor Core Logger - Vertical } \\ \text { NETL } & \text { National Energy Technology Laboratory } \\ \text { NSF } & \text { National Science Foundation } \\ \text { ODP } & \text { Ocean Drilling Program } \\ \text { ODP-LC } & \text { Ocean Drilling Program - Logging Chamber } \\ \text { PCS } & \text { Pressure Core Sampler } \\ \text { PSI } & \text { Pounds per Square Inch } \\ \text { RAB } & \text { Resistivity at the Bit } \\ \text { RAB-c } & \text { Resistivity at the Bit with Coring } \\ \text { RCB } & \text { Rotary Core Barrel } \\ \text { R/V } & \text { Research Vessel } \\ \text { TAMU } & \text { Texas A\&M University } \\ \text { XCB } & \text { Extended Core Barrel } \\ & \end{array}$

